\title{
Front Matter: Volume 8001
}

, "Front Matter: Volume 8001," Proc. SPIE 8001, International Conference on Applications of Optics and Photonics, 800101 (5 August 2011); doi: 10.1117/12.906222

SPIE Event: International Conference on Applications of Optics and Photonics, 2011, Braga, Portugal 


\title{
PROCEEDINGS OF SPIE
}

\section{International Conference on Applications of Optics and Photonics}

Manuel F. M. Costa

Editor

\author{
3-7 May 2011 \\ Braga, Portugal \\ Organized by \\ SPOF-Sociedade Portuguesa para a Investigação e Desenvolvimento em Óptica e Fotónica \\ "Optics and Photonics Portuguese Society" (Portugal) \\ Sponsored by \\ International Commission for Optics \\ Fundação para a Ciência e Tecnologia (Portugal) \\ Cooperating Organization \\ SPIE
}

Volume 8001

Part One of Two Parts 
The papers included in this volume were part of the technical conference cited on the cover and title page. Papers were selected and subject to review by the editors and conference program committee. Some conference presentations may not be available for publication. The papers published in these proceedings reflect the work and thoughts of the authors and are published herein as submitted. The publisher is not responsible for the validity of the information or for any outcomes resulting from reliance thereon.

Please use the following format to cite material from this book:

Author(s), "Title of Paper," in International Conference on Applications of Optics and Photonics, edited by Manuel F. M. Costa, Proceedings of SPIE Vol. 8001 (SPIE, Bellingham, WA, 2011) Article CID Number.

ISSN 0277-786X

ISBN 9780819485755

Published by

SPIE

P.O. Box 10, Bellingham, Washington 98227-0010 USA

Telephone +1 3606763290 (Pacific Time) · Fax +1 3606471445

SPIE.org

Copyright (C) 2011, Society of Photo-Optical Instrumentation Engineers

Copying of material in this book for internal or personal use, or for the internal or personal use of specific clients, beyond the fair use provisions granted by the U.S. Copyright Law is authorized by SPIE subject to payment of copying fees. The Transactional Reporting Service base fee for this volume is $\$ 18.00$ per article (or portion thereof), which should be paid directly to the Copyright Clearance Center (CCC), 222 Rosewood Drive, Danvers, MA 01923. Payment may also be made electronically through CCC Online at copyright.com. Other copying for republication, resale, advertising or promotion, or any form of systematic or multiple reproduction of any material in this book is prohibited except with permission in writing from the publisher. The CCC fee code is 0277-786X/11/ \$18.00.

Printed in the United States of America.

Publication of record for individual papers is online in the SPIE Digital Library.

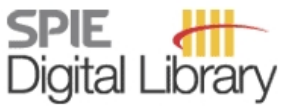

SPIEDigitalLibrary.org

Paper Numbering: Proceedings of SPIE follow an e-First publication model, with papers published first online and then in print and on CD-ROM. Papers are published as they are submitted and meet publication criteria. A unique, consistent, permanent citation identifier (CID) number is assigned to each article at the time of the first publication. Utilization of CIDs allows articles to be fully citable as soon as they are published online, and connects the same identifier to all online, print, and electronic versions of the publication. SPIE uses a six-digit CID article numbering system in which:

- The first four digits correspond to the SPIE volume number.

- The last two digits indicate publication order within the volume using a Base 36 numbering system employing both numerals and letters. These two-number sets start with 00, 01, 02, 03, 04, $05,06,07,08,09,0 A, 0 B \ldots 0 Z$, followed by 10-1Z, 20-2Z, etc.

The CID number appears on each page of the manuscript. The complete citation is used on the first page, and an abbreviated version on subsequent pages. Numbers in the index correspond to the last two digits of the six-digit CID number. 


\title{
Contents
}

\section{Part One}

\author{
xix Conference Committees \\ xxiii Introduction
}

\section{PARALLEL SESSION 1}

800102 Seeing colors in real scenes (Invited Paper) [8001-06]

S. M. C. Nascimento, Univ. of Minho (Portugal)

800103 Lighting spectra for the maximum colorfulness [8001-147] O. Masuda, J. M. M. Linhares, P. E. R. Felgueiras, S. M. C. Nascimento, Univ. of Minho (Portugal)

800104 Color diversity index: the effect of chromatic adaptation [8001-174]

J. M. M. Linhares, Univ. of Minho (Portugal) and Anglia Ruskin Univ. (United Kingdom);

S. M. C. Nascimento, Univ. of Minho (Portugal)

800105 A VDU experimental setup for fixation disparity evaluation [8001-198]

R. A. R. C. Sousa, Clinical Practice, Braga (Portugal); A. M. G. Baptista, Univ. of Minho (Portugal)

800106 Optical scattering properties of a nano-textured ZnO-silicon interface [8001-13] K. Jäger, Delft Univ. of Technology (Netherlands); M. Schulte, K. Bittkau, A. M. Ermes, Forschungszentrum Jülich GmbH (Germany); M. Zeman, Delft Univ. of Technology (Netherlands); B. E. Pieters, Forschungszentrum Jülich GmbH (Germany)

800107 Dynamical manipulation of quadratic non-linearity photonic crystal gap solitons trough thermooptic induced index modulations [8001-119]

F. C. Moreira, Univ. de Lisboa (Portugal); S. B. Cavalcanti, Univ. Federal de Alagoas (Brazil)

800108 Different polynomial expressions for wavefront aberrations (Invited Paper) [8001-217]

D. Malacara-Hernández, Ctr. de Investigaciones en Óptica, A.C. (Mexico);

A. Gomez-Vieyra, Univ. Autónoma Metropolitana (Mexico); R. Rodríguez-Vera, Ctr. de Investigaciones en Óptica, A.C. (Mexico); E. Basurto-Uribe, Univ. Autónoma Metropolitana (Mexico)

800109 Ptychography: a novel phase retrieval technique, advantages and its application [8001-226]

D. Claus, A. M. Maiden, F. Zhang, A. Hurst, T. Edo, F. Sweeney, J. M. Rodenburg, The Univ. of Sheffield (United Kingdom); H. Schluesener, Univ. of Tuebingen (Germany); M. J. Humphry, Phase Focus Ltd. (United Kingdom)

8001 OA Investigating material removal mechanisms during laser ablation of InSb [8001-75] A. Garg, A. Kapoor, K. N. Tripathi, S. K. Bansal, Univ. of Delhi (India) 
$8001 \mathrm{OB} \quad$ A compressive sensing based transmissive single-pixel camera [8001-59]

F. Magalhães, INESC Porto (Portugal) and Univ. of Porto (Portugal); M. Abolbashari,

F. Farahi, The Univ. of North Carolina at Charlotte (United States); F. M. Araújo, INESC Porto

(Portugal); M. V. Correia, INESC Porto (Portugal) and Univ. of Porto (Portugal)

\section{PARALLEL SESSION 2}

8001 OC Silicone hydrogel contact lens surface analysis by atomic force microscopy: shape parameters [8001-68]

M. J. Giraldez, C. Garcia-Resua, Univ. of Santiago de Compostela (Spain); M. Lira, Univ. of Minho (Portugal); C. Sánchez-Sellero, E. Yebra-Pimentel, Univ. of Santiago de Compostela (Spain)

8001 OD Objective categorization of interferential tear film lipid layer pattern: validation of the technique [8001-87]

C. García-Resúa, M. J. Giráldez, Univ. of Santiago de Compostela (Spain); N. Barreira, M. G. Penedo, Univ. A Coruña (Spain); E. Yebra-Pimentel, Univ. of de Santiago de Compostela (Spain)

8001 OE Optometry in Portugal: a historical perspective [8001-278]

E. Teixeira, Associação de Profissionais Licenciados de Optometria (Portugal);

A. M. G. Baptista, Univ. of Minho (Portugal); R. A. R. C. Sousa, Clinical Practice, Braga (Portugal)

8001 OF Optical properties of AIN $O_{y}$ thin films deposited by DC magnetron sputtering [8001-83] J. Borges, Univ. of Minho (Portugal); E. Alves, Instituto Tecnológico Nuclear (Portugal); F. Vaz, L. Marques, Univ. of Minho (Portugal)

$80010 G$ Twenty years of optical coherence tomography: challenges for the future (Invited Paper) [8001-209]

C. Carmelo Rosa, Univ. of Porto (Portugal)

$8001 \mathrm{OH} \quad$ Calculation of optical properties of nanoparticles for biomedical applications [8001-242] J. Joseph, V. M. Murukeshan, L. S. Woh, Nanyang Technological Univ. (Singapore)

8001 Ol A strategy for spectroscopic diagnosis of dysplasia using a miniaturized system for endoscopic capsules [8001-53]

D. S. Ferreira, J. H. Correia, G. Minas, Univ. of Minho (Portugal)

$80010 \mathrm{~J}$ The Mueller-matrix elements characteristic values of biological tissues [8001-31] Y. A. Ushenko, O. V. Dubolazov, A. O. Karachevtcev, Chernivtsi National Univ. (Ukraine); N. I. Zabolotna, Vinnitsa National Technical Univ. (Ukraine)

8001 OK Photoacoustic based surface plasmon resonance spectroscopy: an investigation [8001-266]

K. Sathiyamoorthy, J. Joseph, C. J. Hon, M. V. Matham, Nanyang Technological Univ. (Singapore) 
8001 OL Mode-locked diode laser for long distance precision metrology [8001-20] M. Abreu, D. C. Alves, A. Cabral, J. M. Rebordão, Univ. of Lisbon (Portugal)

8001 OM 2D face database diversification based on 3D face modeling [8001-267]

Q. Wang, J. Li, Old Dominion Univ. (United States); V. K. Asari, Univ. of Dayton (United States); M. A. Karim, Old Dominion Univ. (United States)

8001 ON Study of holographic diffraction gratings implemented in photopolymerizable glasses incorporating ionic liquid [8001-36]

A. V. Velasco, M. P. Hernández-Garay, M. L. Calvo, Complutense Univ. of Madrid (Spain); P. Cheben, National Research Council (Canada); F. del Monte, Spanish Research Council (Spain)

800100 Colliding pulse mode-locked lasers as light sources for single-shot holography [8001-163] D. Grosse, N. Koukourakis, N. C. Gerhardt, T. Schlauch, J. C. Balzer, Ruhr Univ. Bochum (Germany); A. Klehr, G. Erbert, G. Tränkle, Ferdinand Braun Institute (Germany); M. R. Hofmann, Ruhr Univ. Bochum (Germany)

8001 OP Optimization of luminescence properties of $\mathrm{Ln}^{3+}$ :fluorosilicate glasses to fabricate waveguides for photonics applications (Invited Paper) [8001-129]

C. K. Jayasankar, K. Linganna, Sri Venkateswara Univ. (India)

$80010 Q \quad$ Fabrication of microlens arrays on soda-lima glasses with a Nd:YVO 4 laser [8001-39]

D. Nieto, Univ. of Santiago (Spain) and National Univ. of Ireland (Ireland); M. T. Flores-Arias,

Univ. of Santiago (Spain); G. M. O'Connor, National Univ. of Ireland (Ireland);

C. Gómez-Reino, Univ. of Santiago (Spain)

8001 OR Numerical simulations for OPCPA crystals: YCOB performance and use in different regimes [8001-250]

H. Pires, Instituto Superior Técnico (Portugal); M. Galimberti, Rutherford Appleton Lab.

(United Kingdom); G. Figueira, Instituto Superior Técnico (Portugal)

\section{PLENARY SESSION 2}

8001 OS Some applications of liquid crystal panels in diffractive optics (Invited Paper) [8001-140] A. Márquez, Univ. de Alicante (Spain); Á. Lizana, Univ. Autònoma de Barcelona (Spain); I. Moreno, Univ. Miguel Hernández (Spain); C. Iemmi, Univ. de Buenos Aires (Argentina);

J. Campos, M. J. Yzuel, Univ. Autònoma de Barcelona (Spain)

\section{PARALLEL SESSION 4}

8001 OT Dynamic pulsing of a MOPA fiber laser [8001-145]

R. Romero, P. T. Guerreiro, S. T. Hendow, J. R. Salcedo, Multiwave Photonics (Portugal)

8001 OU Characterization of white-light continuum generation in transparent solid media using cross-correlation frequency resolved optical gating (XFROG) [8001-249]

T. Imran, G. Figueira, Instituto Superior Técnico (Portugal) 
8001 OV Laser frequency stability: a simple approach for a quantitative analysis [8001-19]

A. Cabral, M. Abreu, J. M. Rebordão, Univ. of Lisbon (Portugal)

8001 OW Characterization of palladium thin film deposited by pulsed laser deposition [8001-21]

U. Singh, N. Jha, A. Kapoor, Univ. of Delhi (India)

$80010 X \quad$ Interferometry with referencing of wavelength [8001-219]

J. Lazar, O. Čip, M. Čižek, J. Hrabina, Z. Buchta, Institute of Scientific Instruments (Czech Republic)

8001 OY Electro-optic electrodes based on Lithium Niobate Mach Zhender Interferometer Modulators for wearable bioelectric activity recording [8001-130]

M. S. Fernandes, J. H. Correia, P. M. Mendes, Univ. of Minho (Portugal)

$80010 Z$ Resolution improvement in digital holography: comparison between synthetic aperture method and spatial averaging method [8001-224]

D. Claus, The Univ. of Sheffield (United Kingdom); D. Iliescu, B. H. Timmerman,

P. J. Bryanston-Cross, The Univ. of Warwick (United Kingdom)

800110 Planar slab waveguide sensor with a left-handed material substrate [8001-73]

S. A. Taya, Islamic Univ. (Palestinian Territory, Occupied); M. M. Abadla, Al-Aqsa Univ. (Palestinian Territory, Occupied); M. M. Shabat, E. J. El-Farran, Islamic Univ. (Palestinian Territory, Occupied)

800111 Technology development towards a generic InP-based photonic-integration foundry [8001-117]

F. M. Soares, K. Janiak, Fraunhofer Institute for Telecommunications, Heinrich-Hertz-Institut (Germany); R. G. Broeke, BB Photonics (Netherlands); N. Grote, Fraunhofer Institute for Telecommunications, Heinrich-Hertz-Institut (Germany)

800112 Towards single cell spectroscopy and refractometry in microfluidic chip platforms [8001-160]

J. B. Tillak, INESC Porto (Portugal); I. Bernacka-Wojcik, Ciência dos Materiais (Portugal);

D. Barata, Ciência dos Materiais (Portugal) and Biomolecular Diagnostics Lab.,

ITQB-UNL/IBET (Portugal); P. A. S. Jorge, INESC Porto (Portugal); H. Águas, Ciência dos

Materiais (Portugal); A. G. Oliva, Biomolecular Diagnostics Lab., ITQB-UNL/IBET (Portugal)

\section{PLENARY SESSION 3}

800113 Salamanca Pulsed Laser Center: the Spanish petawatt (Invited Paper) [8001-256]

L. Roso, Ctr. de Laseres Pulsados (Spain)

\section{PARALLEL SESSION 5}

800114 Periodic photonic structures in lithium fluoride (Invited Paper) [8001-233]

H. J. Kalinowski, Federal Univ. of Technology Paraná (Brazil) and Instituto de

Telecomunicações (Portugal); I. Chiamenti, Federal Univ. of Technology Paraná (Brazil); R. M. Monterali, M. A. Vincenti, F. Bonfligli, ENEA C.R. Frascati (Italy); F. Michelotti, Univ. di Roma La Sapienza (Italy); R. N. Nogueira, Instituto de Telecomunicações (Portugal) 
800115 A $340 \mathrm{~W}$ monolithically integrated all-fiber laser design using the master oscillator power amplifier configuration [8001-88]

K. Hejaz, A. Babazadeh, R. Poozesh, R. Rezaei-Nasirabad, A. HeydariAzar, A. AsgarAmidian, J. Sabbaghzadeh, Iranian National Ctr. for Laser Science and Technology (Iran, Islamic Republic of)

800116 Structural and optical characterisation of planar waveguides obtained via Sol-Gel [8001-60] F. Rey-García, C. Gómez-Reino, M. T. Flores-Arias, Univ. of Santiago de Compostela (Spain); G. F. De La Fuente, Univ. de Zaragoza (Spain); W. Assenmacher, W. Mader, Univ. Bonn (Germany)

800117 Electro-optical method for polarimetric measurement [8001-218]

L. J. M. Díaz, Ctr. of Technological Applications and Nuclear Development (Cuba)

800118 Atomic transfer between two magneto-optical traps [8001-150] M. Martínez Valado, A. V. Carpentier, H. Michinel, J. A. Nóvoa López, D. Nóvoa Fernández, J. R. Salgueiro, Univ. de Vigo (Spain)

8001 1A Rogue waves as energy concentrators in arrays of coupled nonlinear waveguides [8001-112]

Y. V. Bludov, Univ. of Minho (Portugal); V. V. Konotop, Univ. de Lisboa (Portugal);

N. Akhmediev, The Australian National Univ. (Australia)

8001 1B Experimental characterization of qutrits using symmetric, informationally complete positive operator-valued measures [8001-120]

Z. E. D. Medendorp, Univ. of Toronto (Canada); F. A. Torres-Ruiz, Univ. de Concepción (Chile) and Univ. de La Frontera (Chile); L. K. Shalm, Univ. of Toronto (Canada); G. N. M. Tabia, C. A. Fuchs, Perimeter Institute for Theoretical Physics (Canada); A. M. Steinberg, Univ. of Toronto (Canada)

$80011 \mathrm{C}$ Performance analysis of flat optical comb generation based on recirculating frequency shifter [8001-141]

L. Zhang, Y. Song, S. Zou, Y. Li, J. Ye, R. Lin, Shanghai Univ. (China)

8001 1D Z-scan measurement of the nonlinear response of new materials by using a high-repetition-rate femtosecond laser [8001-158]

J. A. Nóvoa, D. Novoa, H. Michinel, A. V. Carpentier, J. R. Salgueiro, M. Martínez Valado, Univ. de Vigo (Spain); P. Chamorro, P. Martin, Univ. de Valladolid (Spain)

8001 1E High-power Yb:KYW picosecond regenerative amplifier for optical parametric amplifier pumping [8001-252]

C. P. João, Instituto Superior Técnico (Portugal); J. Körner, M. Kahle, H. Liebetrau, R. Seifert, M. Lenski, S. Pastrik, J. Hein, T. Gottschall, J. Limpert, Friedrich-Schiller-Univ. Jena (United States); G. Figueira, Instituto Superior Técnico (Portugal); V. Bagnoud, GSI Helmholtzzentrum für Schwerionenforschung GmbH (United States) and Helmholtz-Institute Jena (Germany)

\section{PLENARY SESSION 4}

8001 1F Nanophotonics inside structured optical fibres (Invited Paper) [8001-16]

J. Canning, The Univ. of Sydney (Australia) 
$80011 G$ Beam transformations by active GRIN materials (Invited Paper) [8001-47]

C. Gomez-Reino, A. I. Gomez-Varela, M. T. Flores-Arias, C. Bao-Varela, Univ. of Santiago

(Spain); X. de la Fuente, Univ. de Zaragoza (Spain)

\section{PARALLEL SESSION 5}

$80011 \mathrm{H} \quad$ Fabrication and characterization of special microstructured fibers (Invited Paper) [8001-08] J. Kobelke, K. Schuster, A. Schwuchow, D. Litzkendorf, R. Spittel, J. Kirchhof, H. Bartelt, Institute of Photonic Technology Jena (Germany)

800111 A simple interrogation technique for refractive index measurement using multimode interference structure [8001-14]

S. Silva, INESC Porto (Portugal) and Univ. of Porto (Portugal); O. Frazão, INESC Porto (Portugal); J. L. Santos, INESC Porto (Portugal) and Univ. of Porto (Portugal); F. X. Malcata, ISMAI (Portugal) and CIMAR/CIIMAR (Portugal)

$80011 \mathrm{~J}$ Generation of few optical cycles in air-silica nanowires [8001-95]

A. Ben Salem, R. Cherif, M. Zghal, Univ. of Carthage (Tunisia)

$80011 \mathrm{~K}$ Modal interferometric sensor based in a birefringent boron-doped microstructured fiber [8001-212]

G. Statkiewicz-Barabach, Wroclaw Univ. of Technology (Poland); J. P. Carvalho, O. Frazão, J. Olszewski, INESC Porto (Portugal); P. Mergo, Maria Curie-Sklodowska Univ. (Poland);

J. L. Santos, INESC Porto (Portugal); W. Urbanczyk, Wroclaw Univ. of Technology (Portugal)

$80011 \mathrm{~L}$ Design of an optical bit memory based on SRS slow light in SOI waveguide [8001-203] M. Ferdosian, H. Kaatuzian, H. Shokri Kojori, Amirkabir Univ. of Technology (Iran, Islamic Republic of)

8001 1M Optical quantum communications: an experimental approach (Invited Paper) [8001-101] A. N. Pinto, Á. J. Almeida, N. A. Silva, N. J. Muga, L. M. Martins, Univ. of Aveiro (Portugal)

$80011 \mathrm{~N}$ Using signal pre-distortion to enhance the performance of all-optical clock recovery [8001-90]

Z. Zhu, Univ. of Science and Technology of China (China)

800110 Crosstalk due to optical demultiplexing in subcarrier multiplexed systems [8001-93]

Z. Zhu, Univ. of Science and Technology of China (China)

$80011 \mathrm{P} \quad$ Nanoring patterning using surface plasmon assisted photolithography [8001-230] R. Sidharthan, K. Sathiyamoorthy, V. M. Murukeshan, Nanyang Technological Univ. (Singapore)

$80011 Q \quad$ Review of optoelectronic oscillators based on modelocked lasers and resonant tunneling diode optoelectronics (Invited Paper) [8001-269]

C. N. Ironside, M. Haji, L. Hou, J. Akbar, A. E. Kelly, K. Seunarine, Univ. of Glasgow (United Kingdom); B. Romeira, J. M. L. Figueiredo, Univ. of Algarve (Portugal)

$80011 R \quad$ Raman distributed fiber laser based in Rayleigh scattering feedback [8001-46]

A. M. R. Pinto, M. Lopez-Amo, Univ. Pública de Navarra (Spain) 
8001 is Laser sources and laser interferometry with optical fibers [8001-159]

B. Mikel, Z. Buchta, J. Lazar, O. Cip, Institute of Scientific Instruments (Czech Republic)

$80011 \mathrm{~T}$ Optoelectronic oscillator topologies based on resonant tunneling diode fiber optic links [8001-173]

B. Romeira, J. M. L. Figueiredo, Univ. of Algarve (Portugal); K. Seunarine, C. N. Ironside, Univ. of Glasgow (United Kingdom)

$80011 \mathrm{E}$ Electromagnetic vacuum of random media [8001-118]

M. Donaire, Univ. of Porto (Portugal)

PARALLEL SESSION 6

$80011 \mathrm{~V}$ Design of dual core resonant leaky fiber for inherent gain flattening of S-band EDFA [8001-127]

K. Kamakshi, V. Rastogi, Indian Institute of Technology Roorkee (India)

$8001 \mathrm{lW}$ Theoretical and experimental study of $\mathrm{mm}$-wave RoF/wireless system based on OFM technique with OFDM modulation [8001-177]

R. Lin, S. Zou, Y. Cai, L. Wei, J. Ye, X. Chen, Y. Li, Shanghai Univ. (China)

$80011 \mathrm{X}$ Optical amplification alternatives for radio over fiber applications [8001-227]

W. Puche, F. Amaya, G. Montoya, J. E. Sierra, Univ. Pontificia Bolivariana (Colombia)

8001 1Y Study of polarimeters based on liquid crystal panels [8001-186]

A. Peinado, A. Lizana, Univ. Autònoma de Barcelona (Spain); J. Vidal, Univ. Autònoma de Barcelona (Spain) and ALBA Synchrotron (Spain); C. Iemmi, Univ. de Buenos Aires (Argentina); J. Campos, Univ. Autònoma de Barcelona (Spain)

800112 Transmission factor of a device containing a liquid crystalline layer between crossed polarizers (Invited Paper) [8001-07]

B. C. Zelinschi, C. F. Dascalu, D. O. Dorohoi, Alexandru Ioan Cuza Univ. (Romania)

\section{PARALLEL SESSION 7}

800120 Integrated optics structures on sol-gel derived organic-inorganic hybrids for optical communications (Invited Paper) [8001-251]

P. S. André, C. M. S. Vicente, V. Fernandes, C. A. F. Marques, E. Pecoraro, R. N. Nogueira, Univ. of Aveiro (Portugal); N. Wada, National Institute of Information and Communications Technology (Japan); L. D. Carlos, Univ. of Aveiro (United States); P. G. Marques,

R. A. S. Ferreira, Univ. of Aveiro (Portugal)

800121 Diffractive optical variable image devices generated by maskless interferometric lithography for optical security [8001-18]

A. Cabral, J. M. Rebordão, Univ. de Lisboa (Portugal) 
800122 Lab on fiber technology and related devices, part I: a new technological scenario; Lab on fiber technology and related devices, part II: the impact of the nanotechnologies (Invited Paper) [8001-239]

A. Cusano, M. Consales, M. Pisco, A. Crescitelli, A. Ricciardi, Univ. of Sannio (Italy);

E. Esposito, National Research Council (Italy); A. Cutolo, Univ. of Sannio (Italy)

800123 Comparative study of different parameters of fibre Bragg gratings and long period gratings sensors for high-temperature measurements [8001-149]

L. B. Melo, Instituto de Telecomunicações (Portugal); N. Ângelo, N. Aberto, Univ. of Aveiro (Portugal); C. Marques, Instituto de Telecomunicações (Portugal); J. Monteiro, G. Rego, P. Caldas, INESC Porto (Portugal) and Escola Superior de Tecnologia e Gestão de Viana do Castelo (Portugal); R. Nogueira, Instituto de Telecomunicações (Portugal)

800124 Simultaneous temperature and refractive index sensor based on a tilted fibre Bragg grating [8001-189]

N. J. Alberto, Univ. of Aveiro (Portugal); C. A. Marques, Instituto de Telecomunicações

(Portugal); J. L. Pinto, Univ. of Aveiro (Portugal); R. N. Nogueira, Instituto de

Telecomunicações (Portugal)

800125 Fiber optic gyroscope assisted by Raman amplification [8001-243]

J. Nuño, J. D. Ania-Castañón, Instituto de Óptica, Daza de Valdés (Spain)

800126 Multi-scale modelling of polymer-based optoelectronic devices (Invited Paper) [8001-109] M. M. D. Ramos, H. M. G. Correia, H. M. C. Barbosa, Univ. of Minho (Portugal)

800127 Computational study of the presence of defects in semiconducting polymers on exciton formation [8001-179]

H. M. G. Correia, H. M. C. Barbosa, M. M. D. Ramos, Univ. of Minho (Portugal)

800128 Integrated optics for astronomical interferometry (Invited Paper) [8001-234]

P. V. S. Marques, INESC Porto (Portugal) and Univ. of Porto (Portugal); A. Ghasempour, Tennessee State Univ. (United States); D. Alexandre, INESC Porto (Portugal), Univ. of Porto (Portugal), and Univ. de Trás-os-Montes e Alto Douro (Portugal); A. M. P. Leite,

P. J. V. Garcia, Univ. of Porto (Portugal); F. Reynaud, XLIM Dept. Photonique/IRO (France)

800129 Imaging LIDAR technology developments at the European Space Agency [8001-62]

J. Pereira do Carmo, European Space Agency (Netherlands)

\section{Part Two}

$80012 \mathrm{~A}$ Optics equations for aero-optical analysis [8001-15]

G. W. Sutton, Cobham Analytic Solutions/Sparta (United States); J. E. Pond, Analysis and Applications, Inc. (United States)

8001 2B Socio-optics: optical knowledge applied in modeling social phenomena (Invited Paper) [8001-271]

R. Chisleag, Polytechnic Univ. of Bucharest (Romania); I.-R. Chisleag Losada, National

School of Political and Administrative Studies (Romania) 
$80012 \mathrm{C}$ Keeping image processing in the optical domain [8001-151]

G. Parca, Instituto de Telecomunicações (Portugal); M. Svaluto Moreolo, Ctr. Tecnològic de Telecomunicacions de Catalunya (Spain); A. Teixeira, Instituto de Telecomunicações (Portugal)

$80012 \mathrm{D}$ Ordering tendency in ternary solutions of pyridazinium ylids evidenced by electron spectroscopy [8001-35]

M. Avadanei, D. O. Dorohoi, Petru Poni Institute of Macromolecular Chemistry (Romania);

N. Puica-Melniciuc, Alexandru loan Cuza Univ. (Romania)

SPECIAL SESSION: OPTICS IN IBERO-AMERICA

8001 2E Advances in optical technologies at Pontificia Universidad Católica del Perú [8001-265]

G. Baldwin, M. Asmad, S. Romero, F. Gonzales, G. Gálvez, R. Sánchez, D. Córdova, Pontificia Univ. Católica del Perú (Peru)

\section{POSTER SESSION 1}

$80012 \mathrm{~F}$ Centroid propagation through optical systems with $A B C D$ kernels and non-uniform or finite apertures (Invited Paper) [8001-103]

J. Lancis, R. Martínez-Cuenca, Univ. Jaume I (Spain); J. Ares, Univ. de Zaragoza (Spain);

S. Bará, Univ. of Santiago de Compostela (Spain)

$80012 \mathrm{G}$ Aluminum nanoparticles production by laser ablation in liquids [8001-245]

V. Damian, C. Udrea, M. Bojan, C. Luculescu, National Institute for Lasers, Plasma and Radiation Physics (Romania); A. Armaselu, Transilvania Univ. of Brasov (Romania); I. Apostol, National Institute for Lasers, Plasma and Radiation Physics (Romania)

$80012 \mathrm{H} \quad$ Photonic instantaneous RF frequency measurement system based on complementary modulation [8001-43]

M. V. Drummond, C. A. F. Marques, P. P. Monteiro, R. N. Nogueira, Univ. of Aveiro (Portugal)

800121 Methods for determination of the main refractive indices of anisotropic layers [8001-05]

C. F. Dascalu, B. C. Zelinschi, D. O. Dorohoi, Alexandru Ioan Cuza Univ. (Romania)

8001 2J Propagation in active GRIN materials: comparison between parabolic and hyperbolic secant complex refractive index profiles [8001-50]

C. Bao-Varela, A. I. Gomez-Varela, M. T. Flores-Arias, C. Gomez-Reino, Univ. of Santiago de Compostela (Spain)

8001 2K Rare earth-doped lead phosphate glasses for visible luminescence [8001-56]

J. Pisarska, L. Żur, W. A. Pisarski, Univ. of Silesia (Poland)

8001 2L Near-infrared luminescence and up-conversion processes of lanthanide ions in heavy metal glasses [8001-57]

W. A. Pisarski, J. Pisarska, Ł. Grobelny, Univ. of Silesian (Poland); R. Lisiecki,

W. Ryba-Romanowski, Institute of Low Temperature and Structure Research (Poland) 
$80012 \mathrm{M}$ Synthesis and evaluation of NLO properties of $\pi$-conjugated donor-acceptor systems bearing pyrrole and thiophene heterocycles [8001-116]

M. C. R. Castro, A. M. C. Fonseca, M. Belsley, M. M. M. Raposo, Univ. of Minho (Portugal)

$80012 \mathrm{~N}$ White light generation in Dy ${ }^{3+}$-doped fluorosilicate glasses for W-LED applications [8001-128] K. V. Krishnaiah, C. K. Jayasankar, Sri Venkateswara Univ. (India)

800120 Physical characterization studies on silver oxide doped $\mathrm{PbO}-\mathrm{Li}_{2} \mathrm{O}-\mathrm{B}_{2} \mathrm{O}_{3}$ glasses [8001-208] J. Coelho, INESC Porto (Portugal); N. S. Hussain, INESC Porto (Portugal) and Univ. do Porto

$80012 \mathrm{P} \quad$ Fabrication of gratings and optical diffractive elements on chalcogenide thin films [8001-153]

V. Kolbjonoks, V. Gerbreders, Daugavpils Univ. (Latvia); J. Teteris, Latvian Univ. (Latvia);

A. Bulanovs, Daugavpils Univ. (Latvia)

$80012 Q \quad$ Family of optoelectronic photocurrent reconfigurable universal (or multifunctional) logical elements (OPR ULE) on the basis of continuous logic operations (CLO) and current mirrors (CM) [8001-238]

V. G. Krasilenko, Open International Univ. of Human Development Ukraine (Ukraine); K. V. Ogorodnik, A. I. Nikolskyy, Vinnitsa National Technical Univ. (Ukraine); V. N. Dubchak, Vinnitsa State Agrarian Univ. (Ukraine)

$80012 R \quad$ Dynamic light scattering study of microemulsion [8001-220]

S. Sharifi, A. Alavi, Univ. of Sistan and Baluchestan (Iran, Islamic Republic of)

800125 Solvatochromism used in determining some molecular electro-optical parameters [8001-65]

L. Stroia, R.-E. Stanculescu, D.-O. Dorohoi, Alexandru Ioan Cuza Univ. of Iasi (Romania)

8001 2T Variable-angle ATR-FTIR studies of depth distribution of amidation in surface modified poly(ethylene terephthalate) [8001-229]

M. Avadanei, Petru Poni Institute of Macromolecular Chemistry (Romania)

$80012 \mathrm{U}$ Highly efficient and thermally stable NLO organic materials based on pyrrole and thiophene heterocycles [8001-181]

M. C. R. Castro, A. M. C. Fonseca, M. Belsley, M. M. M. Raposo, Univ. of Minho (Portugal)

$80012 \mathrm{~V}$ Synthesis and characterization of novel push-pull thiophene and thienylpyrrole derivatives functionalized with indanonedicyanovinyl acceptor moiety as efficient NLO-chromophores [8001-187]

R. M. F. Batista, S. P. G. Costa, M. Belsley, M. M. M. Raposo, Univ. of Minho (Portugal)

8001 2W Complex degree of mutual anisotropy in diagnostics of biological tissues physiological changes [8001-32]

Y. A. Ushenko, O. V. Dubolazov, A. O. Karachevtcev, Chernivtsi National Univ. (Ukraine);

N. I. Zabolotna, Vinnitsa National Technichal Univ. (Ukraine)

$80012 X \quad$ Optical microtopographic inspection of the surface of tooth subjected to stripping reduction [8001-44]

M. F. Costa, Univ. of Minho (Portugal); P. B. Pereira, Univ. of Santiago de Compostela (Spain) 
$80012 Y \quad$ Measurements of optical polarization properties in dental tissues and biomaterials [8001-82] A. Fernández-Oliveras, O. E. Pecho, M. Rubiño, M. M. Pérez, Univ. de Granada (Spain)

800130 Detection of colon cancer by terahertz techniques [8001-122]

F. Wahaia, Univ. of Porto (Portugal); G. Valusis, Semiconductor Physics Institute of Vilnius (Lithuania); L. M. Bernardo, A. Almeida, J. A. Moreira, P. C. Lopes, Univ. of Porto (Portugal); J. Macutkevic, I. Kasalynas, D. Seliuta, R. Adomavicius, Semiconductor Physics Institute of Vilnius (Lithuania); R. Henrique, Univ. of Porto (Portugal); M. Lopes, Portuguese Oncology Institute (Portugal)

800131 Speckle shearing pattern interferometry to assess mechanical strain in the human mandible-jaw bone under physiological stress [8001-148]

V. Moreno, C. Vázquez-Vázquez, M. Gallas, J. Crespo, Univ. of Santiago de Compostela (Spain)

800132 Changes in scattering and absorption during curing of dental-resin composites: silorane and nanocomposite [8001-240]

M. del Mar Pérez, R. Ghinea, A.-M. Ionescu, J. de la Cruz Cardona, Univ. of Granada (Spain)

800133 Vertically dispersive holographic screens and autostereoscopic displays in 3D medical imaging [8001-255]

D. S. F. Magalhães, Hospital das Clínicas da Unicamp (Brazil); R. L. Serra, Instituto Superior Politécnico José Antonio Echeverría (Cuba); A. L. Vannucci, Univ. of Campinas, Unicamp (Brazil); A. B. Moreno, Instituto Superior Politécnico José Antonio Echeverría (Cuba); L. V. B. Magalhães, Hospital das Clínicas da Unicamp (Brazil); J. J. Llovera, Instituto Superior Politécnico José Antonio Echeverría (Cuba); L. M. Li, Hospital das Clínicas da Unicamp (Brazil)

800134 Evaluation of the efficacy and influence of the decontamination and sterilization of FBGs exposed to S. aureus and E. coli [8001-169]

L. Z. Karam, Federal Univ. of Technology of Paraná (Brazil); A. P. G. O. Franco, Pontifical Catholic Univ. of Parana (Brazil); P. Tomazinho, L. Signorini, Positivo Univ. (Brazil); L. Carvalho, Instituto Politécnico de Saúde do Norte (Portugal); M. H. Fernandes, Univ. of Porto (Portugal); M. B. Hecke, Univ. Federal of Paraná (Brazil); H. J. Kalinowski, Federal Univ. of Technology of Paraná (Brazil)

800135 Imaging of aphakic intraocular lens with a slit-scanning tomography system [8001-94] C. M. Oliveira, J. B. Almeida, S. Franco, Univ. of Minho (Portugal)

800136 Modelling image formation on the retina and backscattered light in the human eye with cataracts [8001-126]

I. Kelly-Pérez, INAOE (Mexico); N. C. Bruce, Univ. Nacional Autónoma de México (Mexico);

L. R. Berriel-Valdos, INAOE (Mexico)

800137 New method for measuring thickness in thin transparent medium [8001-195]

R. A. R. C. Sousa, Clinical Practice, Braga (Portugal); A. M. G. Baptista, Univ. of Minho (Portugal)

800138 Effect of the holding setup on the measurement of the crystalline lens aberrations [8001-143] A. Gargallo, J. Arines, E. Acosta, Univ. of Santiago de Compostela (Spain) 
800139 Accommodative and convergence response to computer screen and printed text [8001-86]

A. Ferreira, M. Lira, S. Franco, Univ. of Minho (Portugal)

$80013 \mathrm{~A}$ White light optical profiling to unworn contact lenses surface topography analysis [8001-67] M. J. Giraldez, C. Garcia-Resua, Univ. of Santiago de Compostela (Spain); M. E. Real Oliveira, Univ. of Minho (Portugal); C. Sánchez-Sellero, E. Yebra-Pimentel, Univ. of Santiago de Compostela (Spain)

$80013 B$ Response variability of the red-green color vision system using reaction times (Invited Paper) [8001-104]

J. M. Medina, Univ. of Minho (Portugal); J. A. Díaz, Univ. of Granada (Spain)

\section{POSTER SESSION 2}

$80013 C$ Colorimetric and refractometric measurements of carbon dioxide [8001-100]

C. Gouveia, INESC Porto (Portugal) and Univ. da Madeira (Portugal); A. Markovics, South Trans Danubian Research Cooperative (Hungary); J. M. Baptista, INESC Porto (Portugal) and Univ. da Madeira (Portugal); B. Kovács, South Trans Danubian Research Cooperative (Hungary) and Univ. of Pécs (Hungary); P. A. S. Jorge, INESC Porto (Portugal)

$80013 D$ A numerical simulation of the phenomena in Be plasma [8001-156]

C. Gavrila, Technical Univ. of Civil Engineering Bucharest (Romania); C. P. Lungu, National Institute for Laser, Plasma and Radiation Physics (Romania); I. Gruia, Univ. of Bucharest (Romania)

$80013 E \quad$ Light source for low-coherence interferometry surface diagnostics [8001-193] Z. Buchta, B. Mikel, S. Řeřucha, J. Lazar, O. Číp, Institute of Scientific Instruments (Czech Republic)

8001 3F Design of optical filters based on the compactness of 2D-arrays of dielectric spheres [8001-136]

P. Morales, A. Andueza, J. Sevilla, Univ. Pública de Navarra (Spain)

$80013 G$ Measurement of lateral chromatic aberration by using an imaging spectrometer [8001-102] H. González-Núñez, X. Prieto-Blanco, E. López Lago, M. D. Mouriz, R. de la Fuente, Univ. of Santiago de Compostela (Spain)

$80013 \mathrm{H} \quad$ Yeast metabolic state identification using micro-fiber optics spectroscopy [8001-202] J. S. Silva, C. C. Castro, A. A. Vicente, Minho Univ. (Portugal); P. Tafulo, P. A. S. Jorge, INESC Porto (Portugal); R. C. Martins, Minho Univ. (Portugal)

$800131 \quad$ ATR-FTIR spectroscopic studies of thermally induced conformational changes of PNIPAAm copolymers in solution [8001-231]

M. Avadanei, G. Fundueanu, Petru Poni Institute of Macromolecular Chemistry (Romania) 
$80013 \mathrm{~J} \mathrm{Spectral} \mathrm{reflectance} \mathrm{variations} \mathrm{in} \mathrm{stay-green} \mathrm{and} \mathrm{conventional} \mathrm{maize} \mathrm{hybrids} \mathrm{as} \mathrm{response}$ to population level stress [8001-236]

C. Weber, H. A. Acciaresi, Comisión de Investigaciones Científicas de la Provincia de Buenos Aires (Argentina) and Univ. Nacional de La Plata (Argentina); E. J. Rodríguez, M. Antonietta, Consejo Nacional de Investigaciones Científicas y Técnicas (Argentina); J. J. Guiamet, Comisión de Investigaciones Científicas de la Provincia de Buenos Aires (Argentina) and Univ. Nacional de La Plata (Argentina); J. O. Tocho, Consejo Nacional de Investigaciones Científicas y Técnicas (Argentina)

8001 3K Intermolecular interactions in binary solutions of some pyridazinium ylids studied by visible electron spectroscopy [8001-64]

M. Homocianu, A. Airinei, Petru Poni Institute of Macromolecular Chemistry (Romania);

D. O. Dorohoi, Petru Poni Institute of Macromolecular Chemistry (Romania) and Alexandru Ioan Cuza Univ. of Iasi (Romania)

8001 3L Diffractive masks by confocal microscopy [8001-157]

P. Maceira, V. Moreno, Univ. of Santiago de Compostela (Spain); J. R. Salgueiro, Univ. de Vigo (Spain); F. Guitian, A. Gil, Univ. of Santiago de Compostela (Spain)

$80013 \mathrm{M}$ Is it possible to assess spatial correlations in a system of polarizable particles by measuring its optical response? [8001-171]

R. M. S. Pereira, P. Pereira, G. Smirnov, M. Vasilevskiy, Univ. of Minho (Portugal)

$80013 \mathrm{~N}$ Optimization of polarization control schemes for QKD systems [8001-191]

N. J. Muga, Instituto de Telecomunicações (Portugal) and Univ. of Aveiro (Portugal);

Á. J. Almeida, Instituto de Telecomunicações (Portugal); M. F. Ferreira, Univ. of Aveiro (Portugal); A. N. Pinto, Instituto de Telecomunicações (Portugal) and Univ. of Aveiro (Portugal)

800130 Continuously logical complementary-dual equivalently analog-to-digital converters for the optical systems [8001-204]

V. G. Krasilenko, Vinnitsa Social Economy Institute (Ukraine); A. I. Nikolskyy, Vinnitsa National Technical Univ. (Ukraine); O. V. Krasilenko, National Aviation Univ. (Ukraine); M. A. Nikolska, Vinnitsa National Technical Univ. (Ukraine)

$80013 P \quad$ Testing of optical systems in retroreflection [8001-210]

D. Malacara-Doblado, A. Téllez-Quiñones, A. Gómez-Vieyra, J. Ramírez-Hernández, Ctr. de Investigaciones en Óptica, A.C. (Mexico)

$80013 Q$ Millimeter wave radiometer installation in Río Gallegos, southern Argentina [8001-262] P. F. Orte, Fellowship ANPCYT (Argentina); J. Salvador, CEILAP (CITEDEF-CONICET) (Argentina) and Univ. Nacional de la Patagonia Austral (Argentina); E. Wolfram, R. D'Elia, CEILAP (CITEDEF-CONICET) (Argentina); T. Nagahama, Y. Kojima, R. Tanada, T. Kuwahara, Nagoya Univ. (Japan); A. Morihira, ULVAC Inc. (Japan); E. Quel, CEILAP (CITEDEF-CONICET) (Argentina); A. Mizuno, Nagoya Univ. (Japan)

8001 3R Polarization studies using Jones calculus in under-graduate optics laboratory [8001-108] A. Garg, R. Sharma, V. Dhingra, Univ. of Delhi (India) 
800135 Supercontinuum generation by using photonic crystal fibres made from borosilicate glasses [8001-72]

E. F. Chillcce, R. E. Ramos-Gonzales, F. C. Cruz, C. M. B. Cordeiro, L. C. Barbosa, Univ. Estadual de Campinas (Brazil)

8001 3T Torsion sensor based on a high-birefringent Sagnac loop interferometer [8001-17] M. S. Ferreira, R. M. Silva, O. Frazão, INESC Porto (Portugal)

$80013 \mathrm{U}$ Simultaneous measurement of strain and temperature using the FBG cladding modes based on a core misaligned splice [8001-28]

C. Gouveia, P. A. S. Jorge, J. M. Baptista, O. Frazão, INESC Porto (Portugal)

8001 3V Optical fibre pressure sensors for small scale studies of groundwater flow [8001-51] L. Coelho, INESC Porto (Portugal); N. Freitas, J. M. Baptista, INESC Porto (Portugal) and Univ. da Madeira (Portugal); O. Frazão, INESC Porto (Portugal); J. L. Santos, INESC Porto (Portugal) and Univ. of Porto (Portugal); T. Restivo, J. Marques, Univ. of Porto (Portugal)

$80013 \mathrm{~W}$ Single-photon source using stimulated FWM in optical fibers for quantum communication [8001-52]

Á. J. Almeida, N. A. Silva, N. J. Muga, A. N. Pinto, Univ. of Aveiro (Portugal)

$80013 X \quad$ Brillouin Stokes comb generated in a distributed fiber Raman amplifier [8001-55]

H. F. Martins, M. B. Marques, INESC Porto (Portugal) and Univ. of Porto (Portugal); O. Frazão, INESC Porto (Portugal)

$80013 Y \quad$ An encapsulated fiber optic fuel level sensor [8001-78]

D. Sengupta, M. Sai Shankar, P. Saidi Reddy, R. L. N. Sai Prasad, K. S. Narayana, P. Kishore, National Institute of Technology, Warangal (India)

$80013 Z$ Optical fibre hydrogen sensors based on palladium coatings [8001-79]

L. Coelho, INESC Porto (Portugal); S. F. O. Silva, P. A. R. Tafulo, J. L. Santos, INESC Porto (Portugal) and Univ. of Porto (Portugal); O. Frazão, INESC Porto (Portugal); F. X. Malcata, Instituto Superior da Maia (Portugal) and Univ. Nova de Lisboa (Portugal)

$800140 \quad$ Nanosecond laser micropatterning of optical fibers [8001-96]

M. Nespereira, C. Silva, J. M. P. Coelho, J. M. Rebordão, Univ. of Lisbon (Portugal)

800141 Fabry-Pérot cavities based on chemical etching for high temperature and strain sensing [8001-99]

P. A. R. Tafulo, P. A. S. Jorge, INESC Porto (Portugal); J. L. Santos, INESC Porto (Portugal) and Univ. of Porto (Portugal); O. Frazão, INESC Porto (Portugal)

800142 Side-polished plastic optical fibre as refractive index, cure and viscosity sensor [8001-105] L. Bilro, N. Alberto, Univ. of Aveiro (Portugal); L. M. Sá, Instituto de Telecomunicações (Portugal); J. L. Pinto, Univ. of Aveiro (Portugal); R. N. Nogueira, Instituto de Telecomunicações (Portugal) 
800143 Multichannel dispersion compensation using a simplified approach SFBG design [8001-106] L. M. Sá, C. Marques, Instituto de Telecomunicações (Portugal); N. Alberto, Univ. of Aveiro (Portugal) and I3N (Portugal); R. Nogueira, Instituto de Telecomunicações (Portugal) and Nokia Siemens Networks (Portugal); P. André, Instituto de Telecomunicações (Portugal) and Univ. of Aveiro (Portugal)

800144 Controlling the sensitivity of a non-adiabatic tapered optical fiber for measuring the refractive index using all fiber Sagnac loop interferometer [8001-107] M. I. Zibaii, INESC Porto (Portugal) and Shahid Beheshti Univ. (Iran, Islamic Republic of); P. A. S. Jorge, O. Frazão, INESC Porto (Portugal); H. Latifi, Shahid Beheshti Univ. (Iran, Islamic Republic of)

800145 Interferometric optical fiber inclinometer with dynamic FBG based interrogation [8001-164] C. R. da Silveira, Univ. Federal do Pará (Brazil) and INESC Porto (Portugal); J. P. Carvalho, P. A. S. Jorge, INESC Porto (Portugal); J. W. A. Costa, Univ. Federal do Pará (Brazil); M. T. R. Giraldi, Instituto Militar de Engenharia (Brazil); J. L. Santos, INESC Porto (Portugal);

E. L. Carvalho Júnior, Empresa Amazonense de Transmissão de Energia (Brazil);

D. O. Figueiredo, Empresa Norte de Transmissão de Energia (Brazil); O. Frazão, INESC Porto (Portugal)

800146 Remote optical fiber sensor with Raman amplification [8001-165]

T. V. N. Coelho, INESC Porto (Portugal) and Federal Univ. of Espirito Santo (Brazil);

A. Guerreiro, INESC Porto (Portugal); P. A. S. Jorge, INESC Porto (Brazil); M. J. Pontes, Federal Univ. of Espirito Santo (Brazil)

800147 Plastic optical fibres dopants to obtain gain enlargement and ultrafast optical switching [8001-183]

A. Luísa Mendonça, A. Charas, Instituto de Telecomunicações (Portugal); J. Clark, Politecnico di Milano (Italy) and Cavendish Lab. (United Kingdom); L. Bazzana, A. Nocivelli, Luceat S.p.A. (Italy); G. Lanzani, Politecnico di Milano (Italy); J. Morgado, Instituto de Telecomunicações (Portugal) and Instituto Superior Técnico (Portugal)

800148 Dynamic monitoring of a mobile telecommunications tower with a bi-axial optical FBG accelerometer [8001-188]

P. Antunes, Instituto de Telecomunicações (Portugal) and Univ. of Aveiro (Portugal);

R. Travanca, H. Varum, Univ. of Aveiro (Portugal); P. André, Instituto de Telecomunicações (Portugal) and Univ. of Aveiro (Portugal)

800149 Chirped Bragg grating Fabry-Perot interferometer for nanostrain measurement [8001-213] R. M. Silva, M. S. Ferreira, O. Frazão, INESC Porto (Portugal)

8001 4A Laser cleaning of graffiti in Rosa Porriño granite [8001-142]

M. P. Fiorucci, J. Lamas, A. J. López, Univ. da Coruña (Spain); T. Rivas, Univ. de Vigo (Spain); A. Ramil, Univ. da Coruña (Spain)

8001 4B Design considerations and performance of a compact LED illuminator for microscopes [8001-180]

J. Monteiro, S. K. Mendiratta, Univ. of Aveiro (Portugal); J. C. Cascalheira, Bioptica (Portugal) 
8001 4C Efficient solar-pumped Nd:YAG laser by a double-stage light-guide/V-groove cavity [8001-196]

J. Almeida, D. Liang, Univ. Nova de Lisboa (Portugal)

8001 4D Optical fiber pumping of solar Nd:YAG disc laser [8001-199]

B. do Couto, D. Liang, Univ. Nova de Lisboa (Portugal)

$80014 \mathrm{E}$ Proposal of real-time all in-fiber semi-differintegration for the phase reconstruction of broadband optical pulses [8001-225]

C. Cuadrado-Laborde, CONICET (Argentina); M. V. Andrés, Univ. de Valencia (Spain); J. Lancis, Univ. Jaume I (Spain)

8001 4F High dynamic range measurement of the pulse contrast in a Ti:sapphire/Nd:glass multiterawatt laser [8001-248]

A. Castanheira, L. Cardoso, H. Pires, G. Figueira, Instituto Superior Técnico (Portugal)

$80014 G \quad$ New optical techniques to improve the visibility of graphene on multiple substrates [8001-133]

H. Gonçalves, P. Schellenberg, M. Belsley, L. Alves, C. Moura, Univ. of Minho (Portugal); T. Stauber, Univ. Autónoma of Madrid (Spain)

$80014 \mathrm{H}$ Differential ray tracing analysis of the Schwarzschild objective [8001-81]

X. Prieto-Blanco, D. Mouriz, H. González Núñez, E. López Lago, R. de la Fuente, Univ. of Santiago de Compostela (Spain)

80014 Realisation of the metre by optical frequency comb: applications in length metrology [8001-244]

S. Ferreira-Barragáns, M. M. Pérez-Hernández, B. Samoudi, E. Prieto, Spanish Ctr. of Metrology (Spain)

$80014 \mathrm{~J} \quad$ Modelling of tapered and microstructured fibers [8001-197]

S. R. Carneiro, M. V. Facão, S. C. Latas, M. F. Ferreira, Univ. of Aveiro (Portugal)

$80014 K \quad$ VIS-NIR bend loss sensitive photonic crystal fibers [8001-71]

E. F. Chillcce, T. Allan, C. M. B. Cordeiro, L. C. Barbosa, IFGW-Unicamp (Brazil)

$80014 \mathrm{~L}$ Study on a kind of digital ion trap mass spectrometry [8001-12]

T. Yang, Jilin Province Electric Power Survey and Design Institute (China)

Author Index

xviii 


\title{
Conference Committees
}

\author{
Conference Chair
}

Manuel F. M. Costa, Universidade do Minho (Portugal)

International Scientific Committee

Amparo Pons Martí, Universitat de València (Spain)

Ana Consortini, Università degli Studi di Firenze (Italy)

Anand Krishna Asundi, OPSS (Singapore)

Andrea Cusano, Università degli Studi di Sannio (Italy)

Andrew Moore, Herriot-Watt University (Scotland)

Angel Augier Calderin, INSTEC (Cuba)

Angela M. Guzman, OSA (Colombia)

Carlos Ferreira, SEDOPTICA (Spain)

Clementina Timus, INFLR (Romania)

Cristiano M. B. Cordeiro, Universidade Estadual de Campinas (Brazil)

Daniel Malacara Hernández, Center for Optics Research (Mexico)

Efraín Solarte Rodriguez, RCO (Colombia)

Elsa Hogert, CNEA (Argentina)

Eric Rosas, RIAO \& AMO (Mexico)

Eugene Arthurs, SPIE (United States)

Francis Berghmans, Vrije Universiteit Brussels (Belgium)

Gert von Bally, Universität Münster (Germany)

Gonçalo Figueira, Universidade Nova de Lisboa (Portugal)

Guillermo Baldwin, Pontificia Universidad Católica del Perú (Peru)

Hans Herzig, EOS (Switzerland)

Hai-Ning Cui, University of Nanjin (China)

Hector Rabal, Center for Optics Research (Argentina)

Hugo Thienpont, Vrije Universiteit Brussels (Belgium)

Humberto Michinel, Universidade de Vigo (Spain)

João Manuel Tavares Universidade do Porto (Portugal)

John Canning, University of Sydney (Australia)

Jose Benito Vazquez-Dorrio, Universidade de Vigo (Spain)

José Figueiredo, Universidade do Algarve (Portugal)

José Luis Paz, CTOV (Venezuela)

José Ramiro Fernandes, UTAD (Portugal)

José R. Salcedo, Multiwavephotonics (Portugal)

José Silva Gomes, Universidade do Porto (Portugal)

Lucilia Cescato, Universidade Estadual de Campinas (Brazil)

Luis Miguel Bernardo, Universidade do Porto (Portugal)

Katrina Svanberg, SPIE (United States) 
Kiyofumi Matsuda, AIST, Tsukuba (Japan)

Kim Chew Ng, Monash University (Australia)

Manuel Lopez-Amo, Universidad Pública de Navarra (Spain)

Marcelo Trivi, Universidad Nacional de Mar del Plata (Argentina)

Maria de Jesus Gomes, Universidade do Porto (Portugal)

Maria Josefa Yzuel, Universidad Autonoma de Barcelona (Spain)

Maria Luisa Calvo, ICO (Spain)

Mário Vaz, INEGI (Portugal)

Marta Ramos, Universidade do Porto (Portugal)

Maxim Tomilin, University of Saint Petersburg (Russia)

Miguel Gonzalez Herraez, Universidad de Alcalá (Spain)

Mikiya Muramatsu, Universidade de São Paulo (Brazil)

Monica Landau, CNEA (Argentina)

Mourad Zghal, STO (Tunisia)

Mustafa Erol, Bozok University (Turkey)

Nicolas Martin, FEMTO-ST (France)

Pablo Artal, Universidad de Murcia (Spain)

Paulo Tavares, Universidade do Porto (Portugal)

Pedro Andrés, Universitat de València (Spain)

Radu Chisleag, Technical University of Bucharest (Romania)

Ramón Rodríguez-Vera, $\mathrm{ClO}$ (Mexico)

Rastogi Pramod, EPFL (Switzerland)

Roger Ferlet, Université de Paris (France)

Rogério Nogueira, Telecommunications Institute (Portugal)

Tomas Catunda, Universidade de São Paulo (Brazil)

Sabry Abdel-Mottaleb, Ain-Shams University (Egypt)

Sun Tong, City University (United Kingdom)

Waclaw Urbanczyk, Wroclaw University of Technology (Poland)

Zuqing Zhu, University of Science and Technology of China (China)

Program Committee

Amit Garg (India)

Anand Krishna Asundi (Singapore)

Angel Augier Calderin (Cuba)

Angela M. Guzman (Colombia)

Clementina Timus (Romania)

Efraín Solarte Rodriguez (Colombia)

Eric Rosas (Mexico)

Gonçalo Figueira (Portugal)

Hai-Ning Cui (China)

Humberto Michinel (Spain)

João Manuel Tavares (Portugal)

Joaquim Carneiro (Portugal)

Jose Benito Vazquez-Dorrio (Spain) 


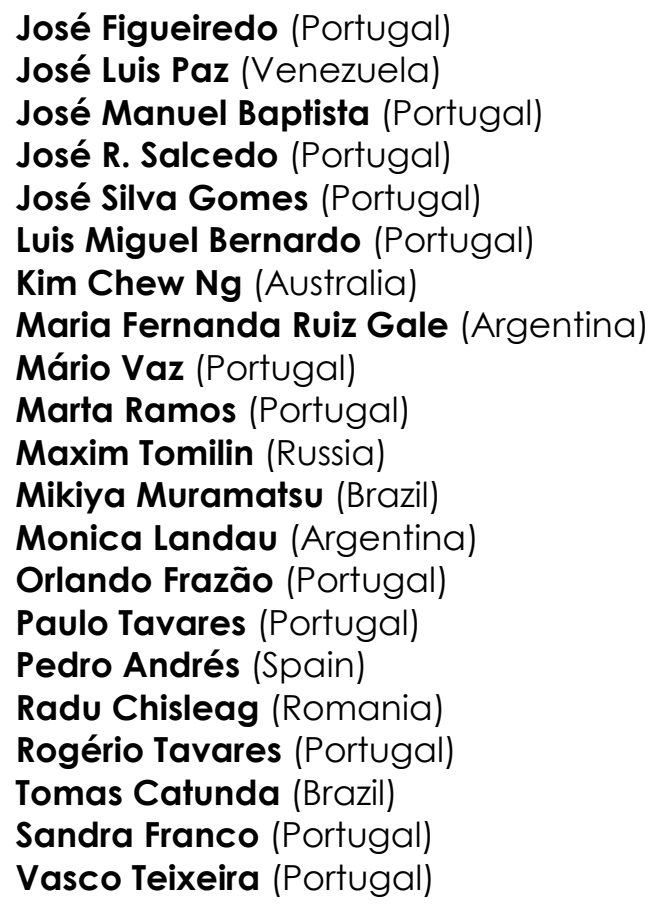

Gonçalo Figueira, Instituto Superior Técnico (Portugal) José Figueiredo, Universidade do Algarve (Portugal) Luis Miguel Bernardo, Universidade do Porto (Portugal) Orlando Frazão, INESC (Portugal)

Rogério Nogueira, Instituto de Telecomunicações (Portugal)

Local Organizing Committee

Ana Cristina Oliveira (Portugal)

Ana João Martins (Portugal)

António Baptista (Portugal)

Cacilda Moura (Portugal)

Gonçalo Figueira (Portugal)

Helena Correia (Portugal)

Ireneu Dias (Portugal)

Jesús Blanco (Spain)

Joel Borges (Portugal)

João Pedro Martins (Portugal)

Joaquim Carneiro (Portugal)

Jose André Pereira (Portugal)

Jose Benito Vazquez-Dorrio (Spain) 
José Figueiredo (Portugal)

José Manuel Baptista (Portugal)

José Ramiro Fernandes (Portugal)

Jose R. Salcedo (Portugal)

Lucia Bilro (Portugal)

Luis Cunha (Portugal)

Luis Marques (Portugal)

Luis Miguel Bernardo (Portugal)

Madalena Lira (Portugal)

Manuel Filipe Costa, Chair (Portugal)

Maria de Jesus Gomes (Portugal)

Mário Pereira (Portugal)

Mário Vaz (Portugal)

Marta Miranda (Spain)

Marta Ramos (Portugal)

Mikiya Muramatsu (Brazil)

Orlando Frazão (Portugal)

Pedro Jorge (Portugal)

Paulo Tavares (Portugal)

Ricardo Sousa Estrada (Portugal)

Rogério Nogueira (Portugal)

Roxana Arvinte (Romania)

Sandra Franco (Portugal)

Teresa Aroso (Portugal)

Vasco Teixeira (Portugal)

Zamith Silva (Portugal) 


\section{Introduction}

The International Conference on Applications of Optics and Photonics (AOP2011) ran very successfully in an exciting, friendly, and rewarding way. 257 participants openly shared ideas and experiences, discussing the remarkable and exciting recent developments in optics and photonics and preparing new development paths and cooperation projects.

The conference was held May 3-7 2011 at the University of Minho and the Melia Braga Hotel and Spa in Braga, Portugal. It was the first major international organization of the Portuguese Society for Research and Development of Optics and Photonics (SPOF-Sociedade Portuguesa para a Investigação e Desenvolvimento em Óptica e Fotónica, contact@spidof.pt).

The Portuguese Optics and Photonics Society was established in November 2009, reflecting the development of scientific and technological research in optics and photonics in Portugal over the last decades and our main goal of promoting the development of optics and photonics in general, particularly in Portugal. Coming from all Portuguese continental and Atlantic autonomous regions, SPOF has an increasing membership of over fifty regular members and a good number of student members working in almost all fields of pure and applied research at university and research institutions, as well as in education and industry services.

The conference was organized to foster the establishment of the widest range of cooperation projects and relationships with colleagues and institutions from all around the world while increasing the external visibility of Portugal' optics and photonics research.

The success of the conference was only possible with the commitment of the vast majority of Portuguese optics and photonics scientists, as well as the endorsement support, active participation, and leadership of the most important international scientific optics societies including ICO, SPIE, OSA, EOS, Photonics'21, RIAO, and SECPhO, and several national societies, committees, and boards including SEDOPTICA, AMO, CTOM, STO, OPSS, CVO, APLO, SPF, FCT, and the contributions of over 460 authors and co-authors from 47 countries of the five continents.

38 invited lectures from world-leading scientists, including nine plenary lectures, gave an excellent overview of the state of the art in optics and photonics research across the world, pointing out future development perspectives.

From the 256 works accepted in all fields of optics and photonics, 237 (103 posters

and 134 oral) were effectively presented. Over 150 full papers were received and 
accepted for publication in these proceedings.

Almost $40 \%$ of the works presented at the conference originated in Portugal, giving the widest representation of research currently being done in Portuguese research institutions. Spain's representation was also remarkable, with nearly $20 \%$ of the conference participants.

The conference counted 257 effective participants (plus 85 undergraduate students in the May 3 and 5 sessions on vision sciences and optometry). Although $3 / 4$ of the participants came from Europe, Asia and Latin America had also major representations.

One third of all participants were students, a good percentage of which came from developing countries. Roughly $50 \%$ of the Portuguese participants were $\mathrm{PhD}$ and masters students, illustrating the vitality and growth potential of Portugal's research in optics and photonics.

The participation of women optics scientists is also notable, both in the quality of the works presented and the number of participants rising up to nearly one third of the total. It is also positive that the percentage of female students rose to $40 \%$. The importance of women in optics has long been recognized by the community. The conference's first plenary speakers were five of the most distinguished optics women scientists, including former and current ICO, SPIE, and OSA presidents.

SPOF and the Portuguese Optics and Photonics community will continue actively working towards the development of optics in Portugal and in general. In September 2013 we will host the 8th Ibero-American Optics Meeting (RIAO/OPTILAS)in Portugal, and in the spring of 2014 the next AOP conference will be organized.

We are looking forward to welcoming you all in Portugal to share with us the remarkable foreseeable developments of optics and photonics!

Manuel F. M. Costa Conference Chair 


\section{FCT Fundação para a Ciência e a Tecnologia} MINISTÉRIO DA CIÊNCIA, TECNOLOGIA E ENSINO SUPERIOR Portugal
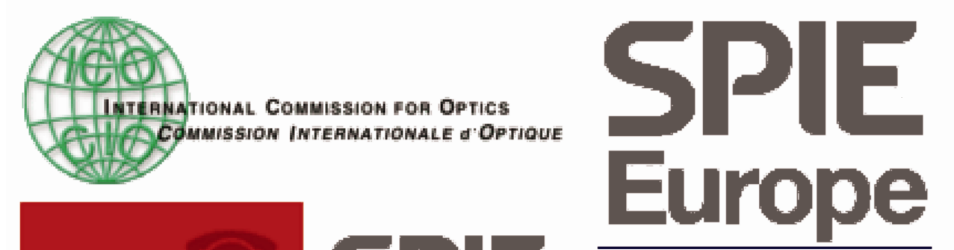

\section{SPIE}

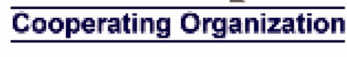
ミSEDOPTICA

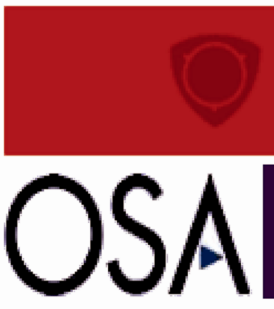
EOS

Coherence for Europe

RIAOF

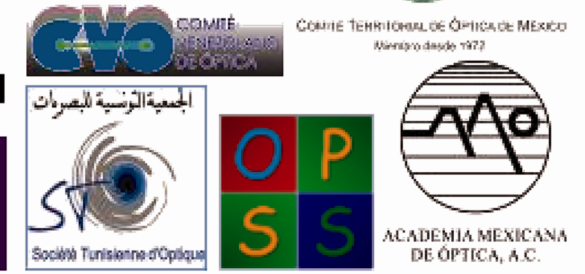

Universidade do Minho
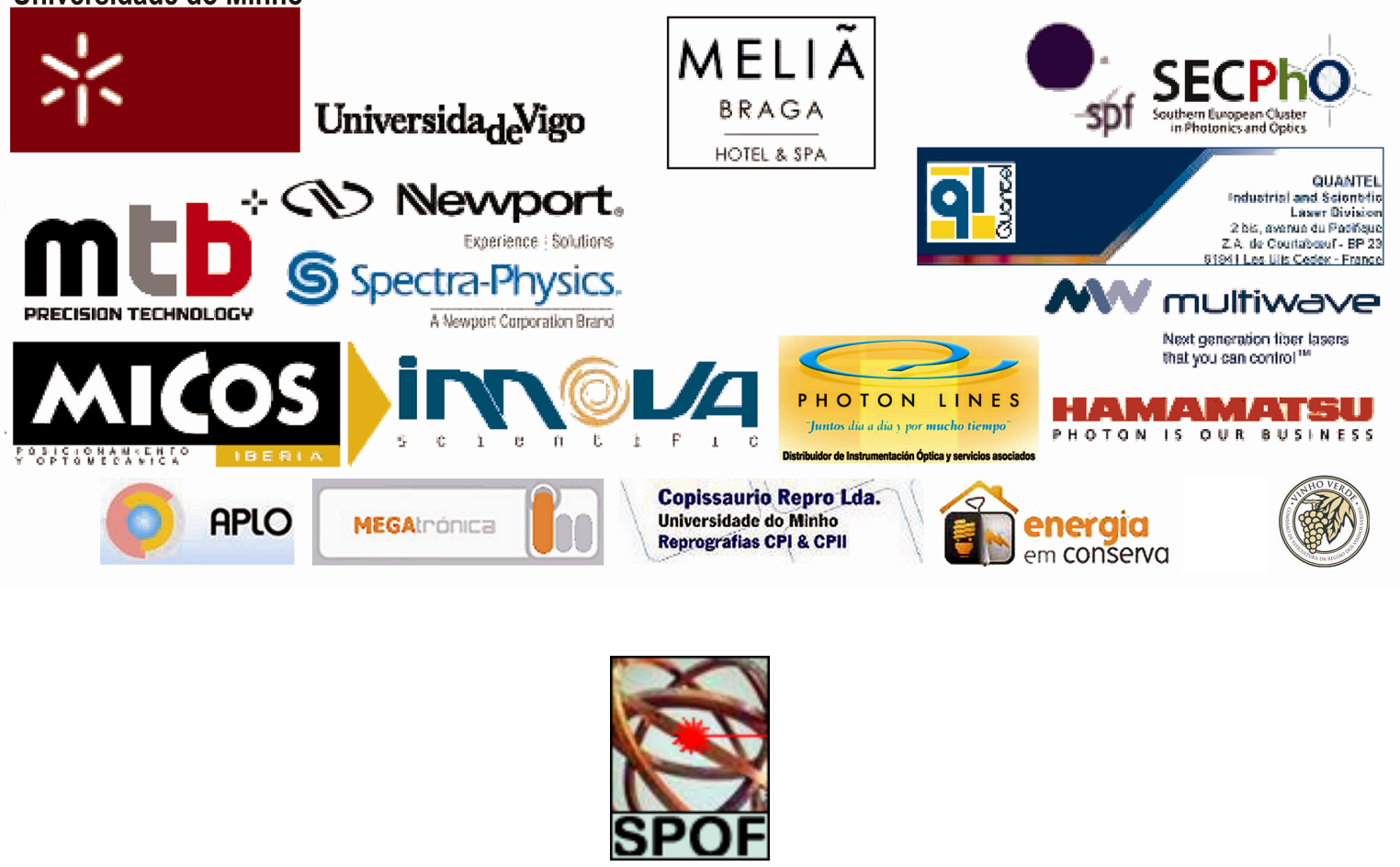

SPOF_Sociedade Portuguesa para a Investigação e Desenvolvimento em Óptica e Fotónica contact@spidof.pt

Rua $1^{\circ}$ de Maio, $2,2^{\circ}, 4730-734$ Vila Verde, Portugal 
Downloaded From: https://www.spiedigitallibrary.org/conference-proceedings-of-spie on 26 Apr 2023

Terms of Use: https://www.spiedigitallibrary.org/terms-of-use 